\title{
REGENERATIVE ENERGY STORAGE SYSTEM FOR SPACE EXPLORATION MISSIONS
}

\author{
Ivar Wærnhus $^{(1)}$, Crina S. Ilea ${ }^{(1)}$, Arild Vik ${ }^{(1)}$, Dimitrios Tsiplakides ${ }^{(2)}$, Stella Balomenou ${ }^{(2)}$, Kalliopi Papazisi $^{(2)}$, \\ Max Schautz ${ }^{(3)}$
}

(1) CMR Prototech AS, Fantoftvegen 38, 5072 Bergen, NORWAY, Email: ivar.warnhus@prototech.no

(2) Centre for Research and Technology - Hellas (CERTH, 6th km Charilaou-Thermi Rd.,

GR-57001Thessaloniki, GREECE,Email: dtsiplak@cperi.certh.gr

(3) European Space Agency, ESTEC -Keplerlaan 1, 2201 AZ Noordwijk Zh, The Netherlands, Email: max.schautz@esa.int

\begin{abstract}
This paper describes the development and testing of a 1 $\mathrm{kW}$ reversible solid oxide fuel cell intended for energy storage on space exploration missions, particularly for long term Mars exploration. The energy is stored as $\mathrm{H}_{2}$ or $\mathrm{CO}$ produced by electrolysis of $\mathrm{H}_{2} \mathrm{O}$ or $\mathrm{CO}_{2}$. The reactants are then converted back to its original composition by producing electricity.

The breadboard was operated for 1250 hours alternating between electrolyser mode and fuel cell mode with $\mathrm{H}_{2} / \mathrm{H}_{2} \mathrm{O}$ as reactants. During the tests, as long as the mechanical integrity of the system was maintained, no degradation effect was observed. At the end of the test period, the fuel cell was operated for three full cycles (approx. 50 hours) with $\mathrm{CO} / \mathrm{CO}_{2}$ as reactants. The performance on $\mathrm{CO} / \mathrm{CO}_{2}$ was lower than for hydrogen, but sufficient to be used in a compact energy storage system for Mars exploration.
\end{abstract}

\section{INTRODUCTION}

Future exploration missions, including human missions to the Moon and Mars, are expected to have increasingly demanding operational requirements. Generating electrical power, as well as maintaining a specific thermal environment, are both critical capabilities for any mission. However, in the case of exploration, both a wide range of mission types (robotic, human, ISRU etc.) and a variety of environments exist; from interplanetary space to the attenuated and redshifted lighting on the Martian surface. Different technologies already exist to provide power in different operating conditions, and in different types of space missions, including Batteries, Solar Arrays, Nuclear Systems and Fuel Cell Technologies.

The present research focuses on a regenerative solid oxide fuel cell system (RSOFCS) that use $\mathrm{H}_{2} \mathrm{O}$ or $\mathrm{CO}_{2}$ as main medium. These cells when charging absorb electric energy and electrolyse $\mathrm{H}_{2} \mathrm{O}$ and/or $\mathrm{CO}_{2}$ into $\mathrm{H}_{2}$ and/or $\mathrm{CO}$ and $\mathrm{O}_{2}$. These two reactant gasses are then stored. When the cells discharge, $\mathrm{H}_{2} / \mathrm{CO}$ and $\mathrm{O}_{2}$ are recombined back into $\mathrm{H}_{2} \mathrm{O} / \mathrm{CO}_{2}$ with production of electric energy. $\mathrm{CO}_{2}$ is available directly from the Martian atmosphere, which means that no reactants need to be carried by the space craft, representing a mass reduction of about $50 \%$.

Previous papers have shown the feasibility of operating with $\mathrm{CO}$ as fuel [1] and the reversibility of the RSOFC electrodes on single cells and short stacks $[2,3]$. CO is in general an unstable molecule that may decompose to solid carbon blocking the active surface or transport channels. It was therefore decided to demonstrate the closed loop system with $\mathrm{H}_{2} / \mathrm{H}_{2} \mathrm{O}$ as reactants. Due to the high cooling flow needed for a standard SOFC, it was not possible to replace air with pure oxygen, which is certainly needed for space operation, during the long term testing. Thus, for the tests presented here, the breadboard is operated with air under atmospheric conditions and no storage of oxygen.

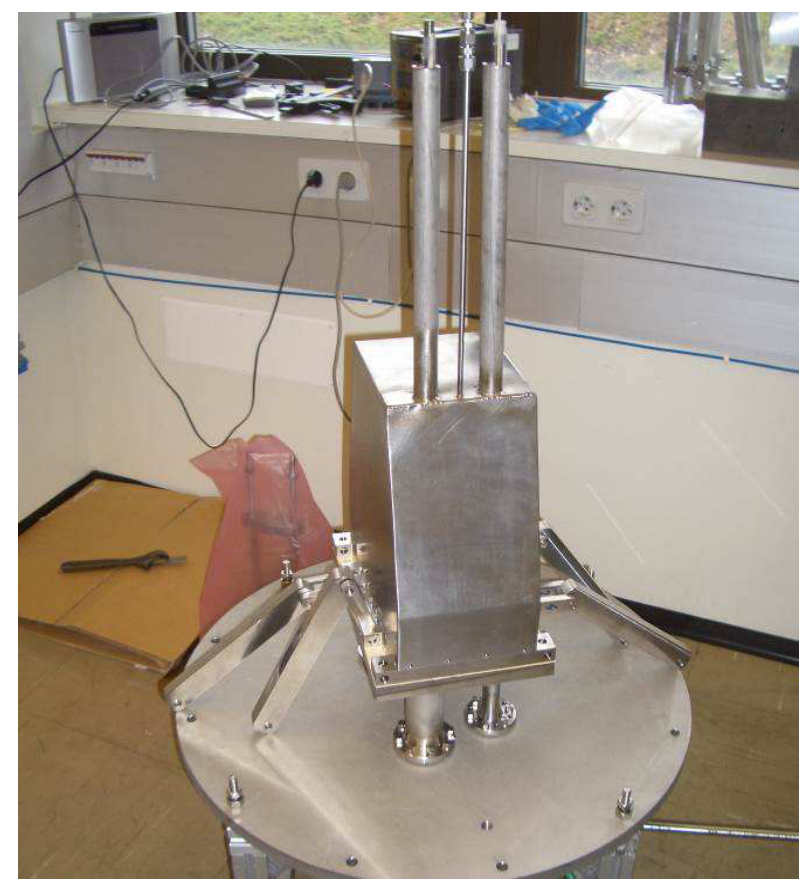

Figure 1. RSOFC stack box 
This paper describes the construction and test results from a $1 \mathrm{~kW}$ RSOFC operated for $>1000$ hours on $\mathrm{H}_{2} / \mathrm{H}_{2} \mathrm{O}$, and for $>50$ hours on $\mathrm{CO} / \mathrm{CO}_{2}$ carried out under ESA contract no 4000105059. In the ongoing activity (4000108849/13/NL/EK) these shortcomings will be addressed and a test program on $\mathrm{CO} / \mathrm{CO}_{2} / \mathrm{O}_{2}$ at elevated pressures representing a full Martian winter season (180 sols) is prepared.

\section{EXPERIMENTAL}

The system includes the following main components:

- A SOFC fuel cell inside a heated chamber,

- Electrical heaters + gas-gas and gas-water heat exchangers for thermal control and water evaporation,

- Compressors and gas tanks for gas storage up to 6 bar,

- Water separators and steam generator, and

- Circulation fan for cooling.

The RSOFC consists of two 30 layer CFY-stacks from
Plansee/IKTS [4] numbered stack 2, stack 3 and stack 4. The stacks were mounted on top of each other with a common fuel manifold and an external air manifold designed for both stacks (Fig. 1). The compressors were diaphragm pumps from Air Dimensions suitable for both $\mathrm{H}_{2}$, and $\mathrm{CO}$. The storage tanks were two ordinary steel tanks ( 2 x 500 litres / 10 bars) able to store ca 9000 normal litres $(\mathrm{Nl})$ of $\mathrm{H}_{2}$, sufficient for $7 \mathrm{kWh}$ of electricity. Due to the large surface area of the stack (130 mm x $150 \mathrm{~mm}$ ), a high cooling flow was required, thus the stack was operated on air, with high excess air flow, both in fuel cell and electrolyzer mode, respectively. The focus for this test was to demonstrate the reversibility of the materials on a real size application, i.e. $1 \mathrm{~kW}$ stack.

The following test program and defined success targets were applied: i) Fuel cell mode: $0.5 \mathrm{~kW}$ for 5 hours followed by $1 \mathrm{~kW}$ for 4 hours; ii) Electrolyzer mode: Fuel for $7 \mathrm{kWh}$ of electricity produced in 7 hours; iii) Continuous testing for 1000 hours with less than $10 \%$ degradation, and iv) Two full electrolysis / fuel cell cycles starting with $\mathrm{CO} 2$ and producing $\mathrm{CO}$ as fuel.
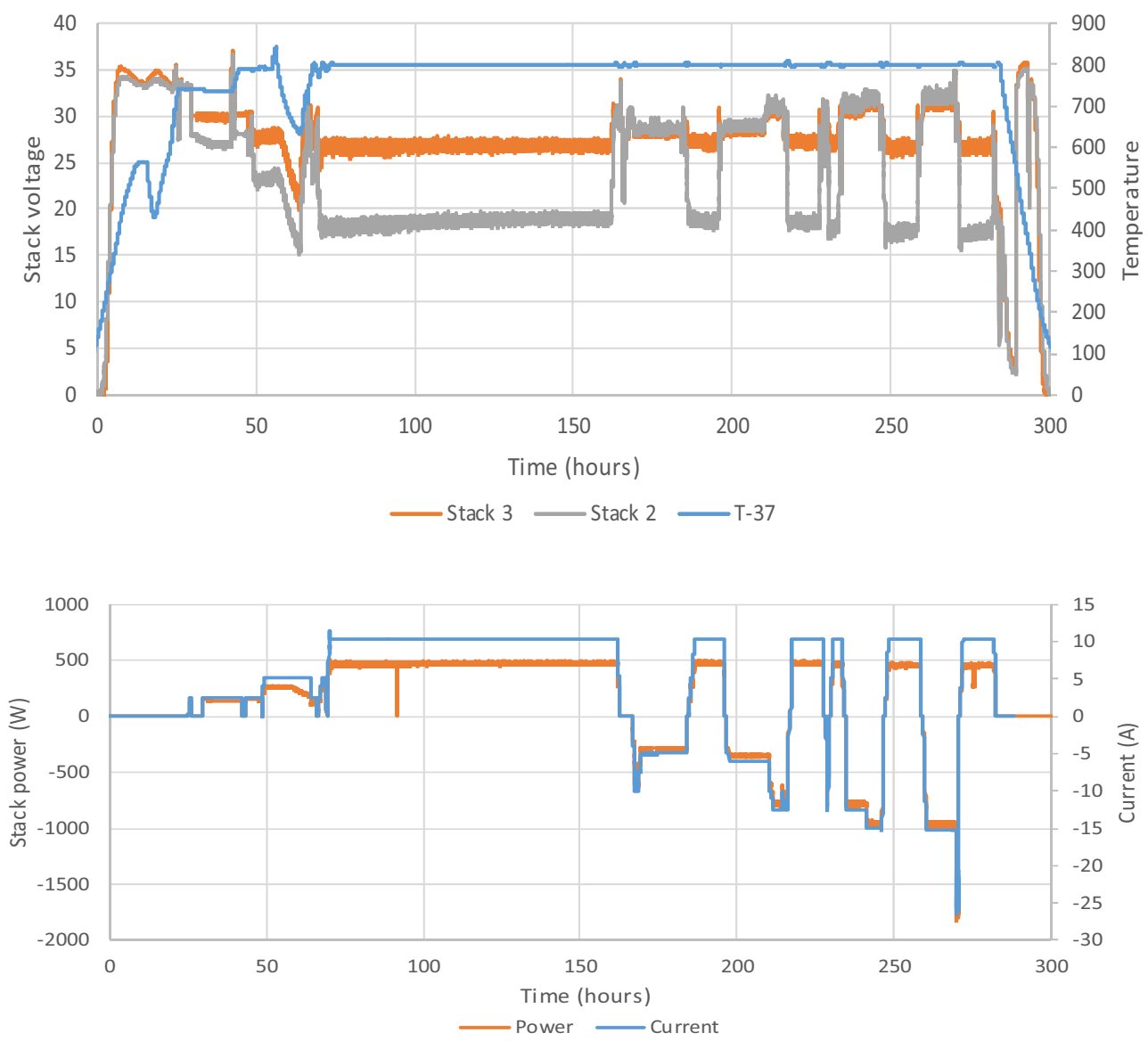

Figure 2. Stack voltage, current, power and temperature during first 300 hours. 


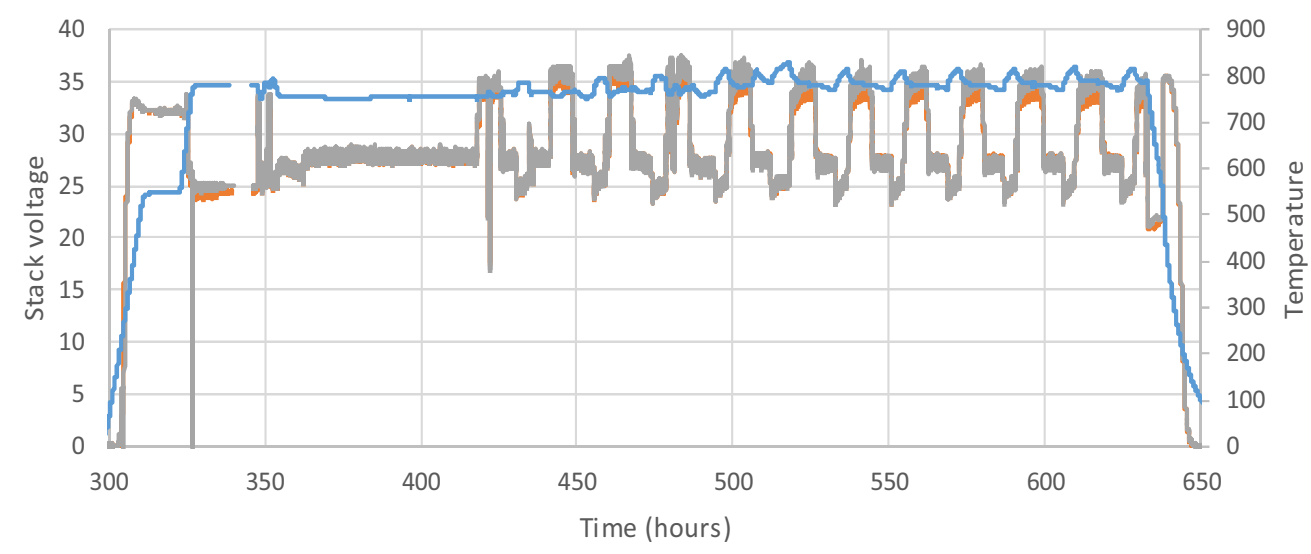

- Stack $3 \longrightarrow$ Stack $4-$ T-37

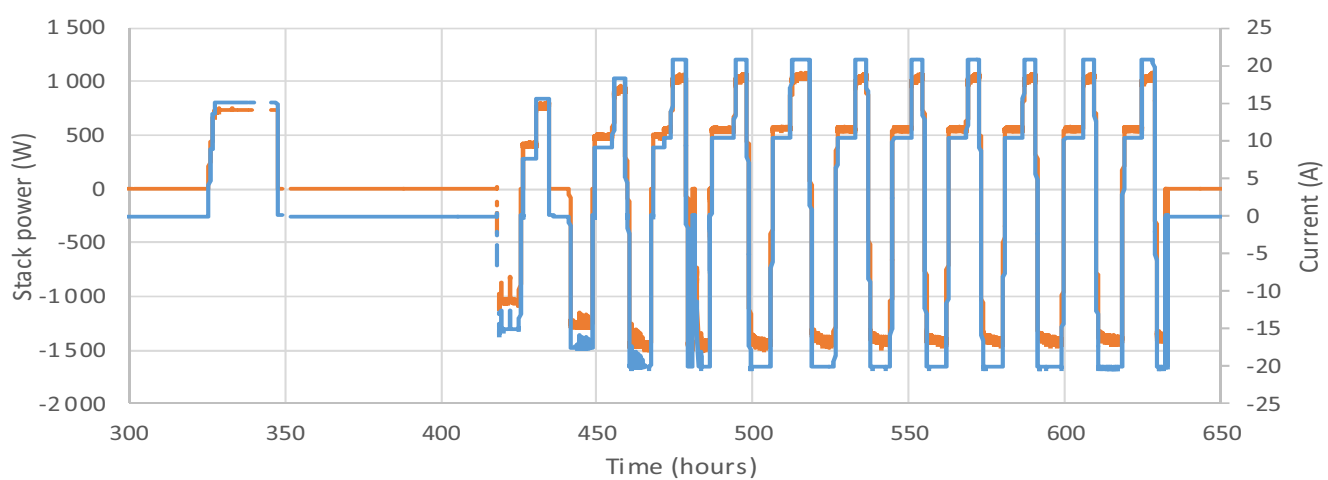

Figure 3. Stack voltage, current, power and temperature from hour 300 to 650.

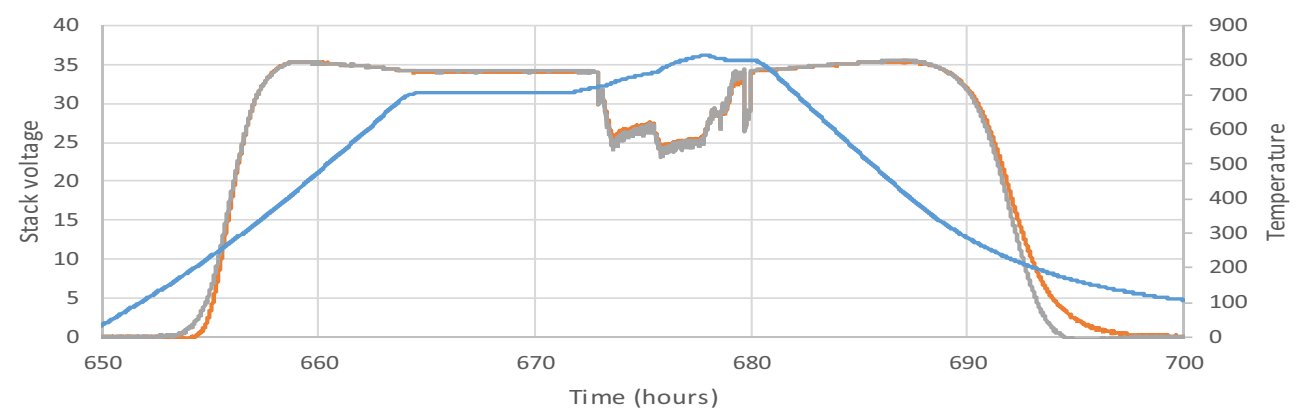

Stack $3 \longrightarrow$ Stack $4 \longrightarrow$ T-37

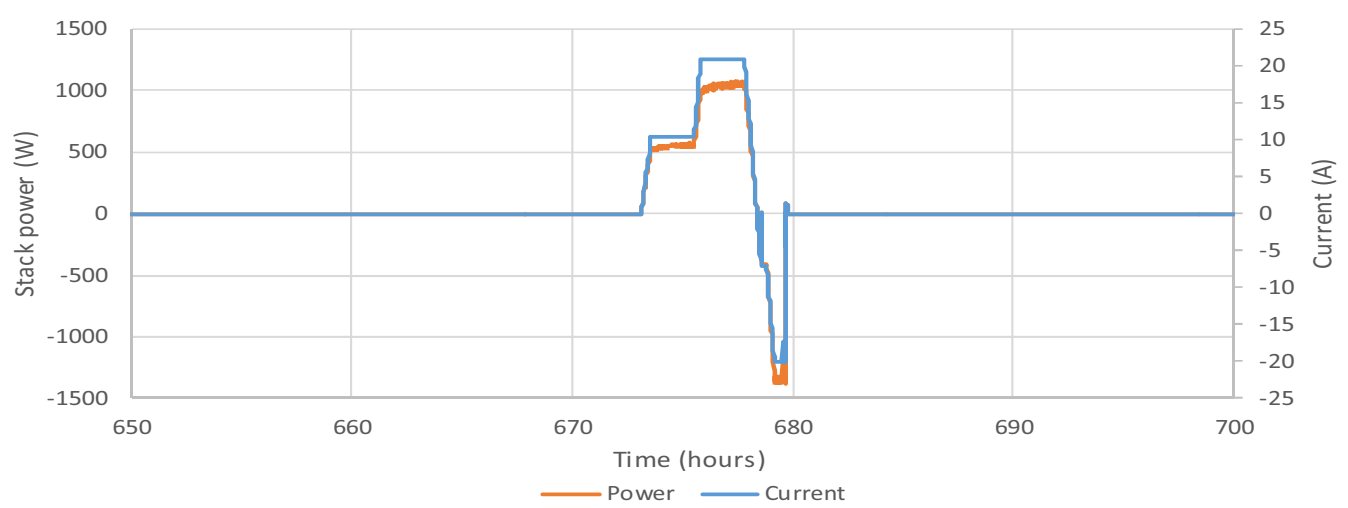

Figure 4. Stack voltage, current, power and temperature hour 650 to 700. 

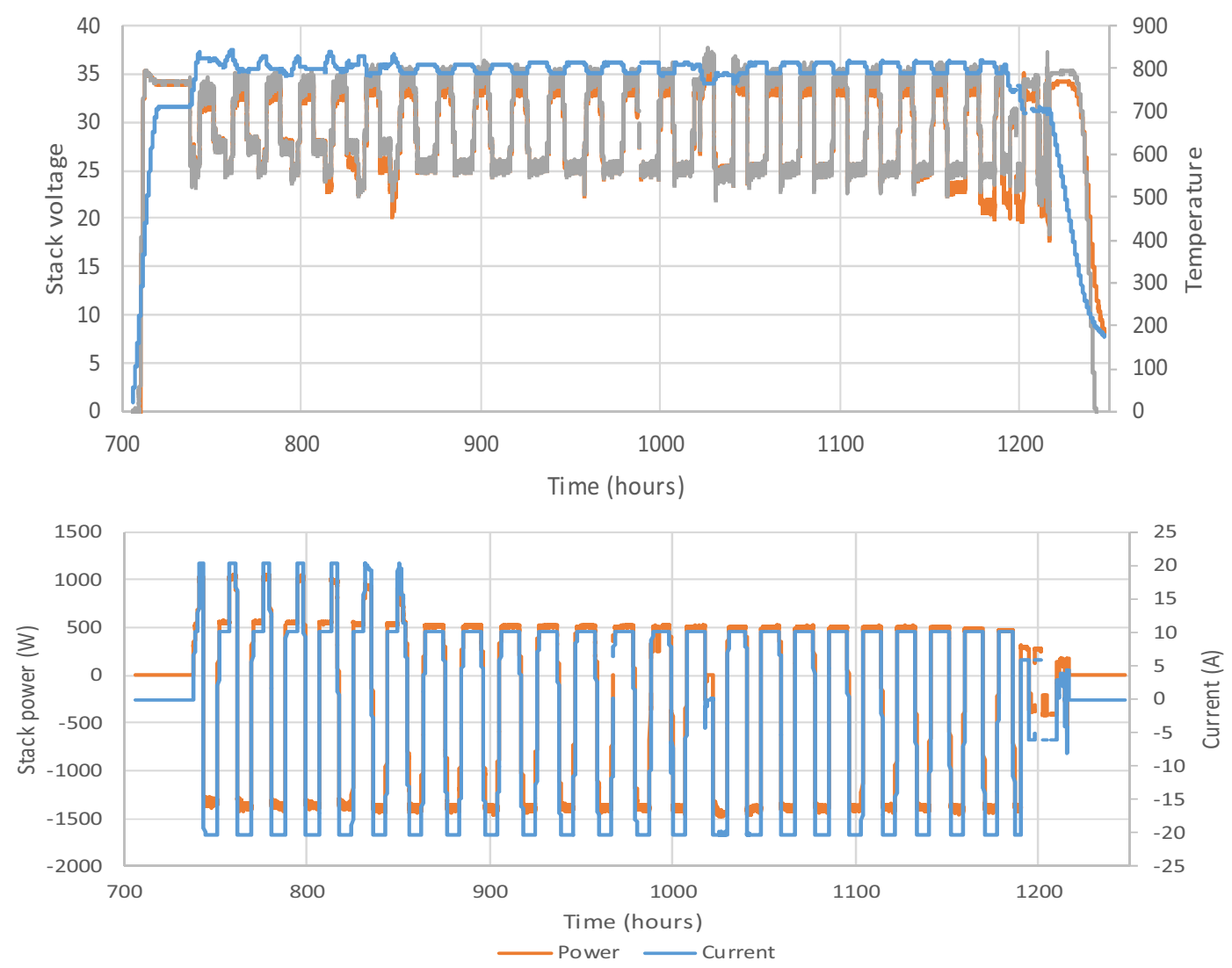

Figure 5. Stack voltage, current, power and temperature from hour 700 to 1250.

\section{RESULTS AND DISCUSSIONS}

\subsection{Fuel cell performance on $\mathrm{H}_{2} / \mathrm{H}_{2} \mathrm{O}$}

Figure 2 to figure 5 shows the observed stack voltages (stack 2, stack 3 and stack 4), temperatures, electric power and stack current during the long term $\mathrm{H}_{2} / \mathrm{H}_{2} \mathrm{O}$ test cycles. The data is separated into four different data sets, each including one thermal cycle. The first 300 hours were also used to tune the automatic control system. It was also observed that stack 2 did not show the expected performance and it was decided to run down the SOFC and replace the stack with stack no 4. The two next thermal cycles, after 650 and 700 hours, were due to some technical issues with the external power supply powering the stack during electrolysis. When these issues were solved, the system could operate uninterrupted until 1250 hours.

At 830 hours (Fig. 5), the cell voltage at 20 A dropped significantly compared to the previous cycle, indicating an initial failure of the stacks. To avoid further damage, the rest of test was limited to $500 \mathrm{~W}$ and $10 \mathrm{~A}$ in fuel cell mode.

Typical performance of two full cycles is shown in
Fig. 6. The voltage measurements are averaged for one minute for reducing the noise level of the data. Here, the system is starting in fuel cell mode, first at $10 \mathrm{~A}$ for 6 hours producing $565 \mathrm{~W}$ before the current was increased to $20 \mathrm{~A}$ for 4 hours, providing $1065 \mathrm{~W}$. Then the current was reduced to zero and reversed to -20 A producing $\mathrm{H}_{2}$ for 7 hours, with power consumption of $1390 \mathrm{~W}$. Thus, each cycle produces $7.65 \mathrm{kWh}$ in fuel cell mode and consumes $10.36 \mathrm{kWh}$ in electrolysis mode, giving a round trip efficiency of $74 \%$.

To calculate the degradation, the recorded data at identical currents were compared. Fig. 7 shows the performance of each stack at 10.4 A and 20.9 A (fuel cell mode) and -20.2 A (electrolysis mode). The data from both fuel cell operation modes (at $10 \mathrm{~A}$ and $20 \mathrm{~A}$ ) show essentially no degradation up to 830 hours. However, after 830 hours some degradation is evident. On the other hand, the electrolysis mode seemed to be unaffected by the 830 hour incident, no degradation was observed during electrolysis mode. The difference in performance at the beginning and at the end of the experiments reveals a total degradation of $8.5 \%$, measured at constant current of $10.4 \mathrm{~A}$, which is within the project target of $<10 \%$. However, for the first 800 

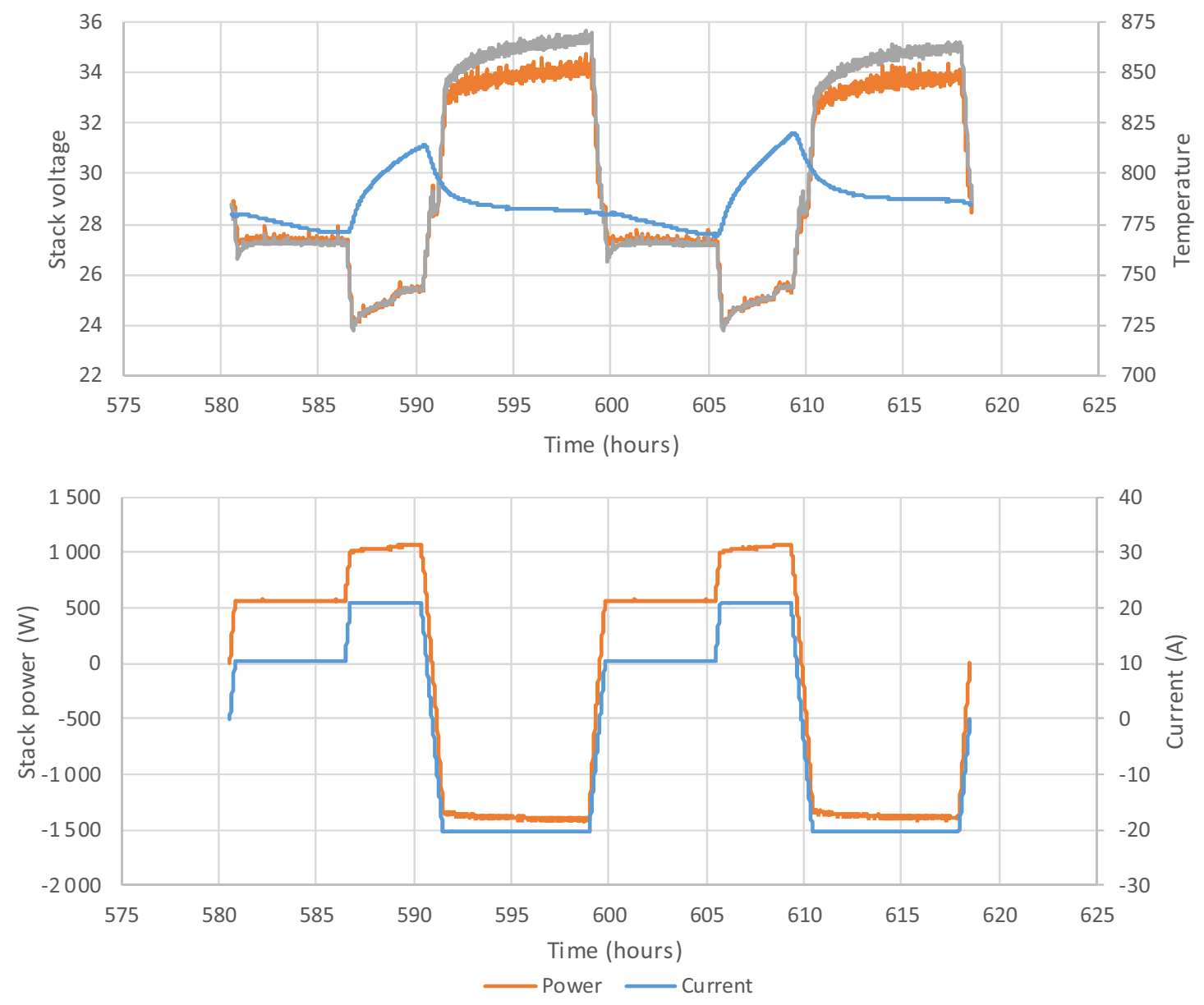

Figure 6. Stack voltage, current, power and temperature during two full cycles

hours, there is essentially no degradation, or at least less than $1 \%$ per 1000 hours, also including three thermal cycles. It is expected that degradation rates $<1 \% /$ khour can be reached for systems operating also for longer periods when the thermal and mechanical system is sufficiently robust.

\subsection{Fuel cell performance on $\mathrm{CO} / \mathrm{CO}_{2}$}

After 1250 hours successfully operation on $\mathrm{H}_{2} / \mathrm{H}_{2} \mathrm{O}$, the system was tested with $\mathrm{CO}_{2}$ replacing $\mathrm{H}_{2} \mathrm{O}$ as the starting gas for electrolysis. Previously, $\mathrm{CO}$ from bottles has been successfully tested as SOFC fuel [1], but this experiment was the first demonstration of an energy storage system using $\mathrm{CO}_{2}$ as starting reactant. Data for stack no 4 (voltage, current and temperature) is given in Fig. 8. The electrolysis voltage has increased from 34.7 $\mathrm{V}$ at $-20 \mathrm{~A}$ to $36.5 \mathrm{~V}$ at $17.5 \mathrm{~A}$ and the fuel cell voltage drops from $27.5 \mathrm{~V}$ at $10 \mathrm{~A}$ to $23.3 \mathrm{~V}$ at $7.0 \mathrm{~A}$ when $\mathrm{H}_{2} \mathrm{O}$ is replaced with $\mathrm{CO}_{2}$. The lower performance is a result partly of slower reaction rates for $\mathrm{CO}$ than for $\mathrm{H}_{2}$, partly of reduce fuel quality since unconverted $\mathrm{CO}_{2}$ in the produced fuel could not be separated from the $\mathrm{CO}$ such as $\mathrm{H}_{2} \mathrm{O}$ can be separated from the hydrogen. Still, the round trip efficiency at cell level is close to $64 \%$, which is an acceptable level.

Using the observed OCV of $28.8 \mathrm{~V}$ for both gas compositions, the area specific resistance (ASR) of stack no 4 during electrolysis increased from 1.25 $\Omega \cdot \mathrm{cm}^{2}$ to $1.86 \Omega \cdot \mathrm{cm}^{2}$, an increase of $0.6 \Omega \cdot \mathrm{cm}^{2}$. Calculations of ASR from in fuel cell mode using the observed OCV $\left(30.2 \mathrm{~V}\right.$ for $\mathrm{H}_{2} / \mathrm{H}_{2} \mathrm{O}$ while only $27.8 \mathrm{~V}$ for $\mathrm{CO} / \mathrm{CO}_{2}$ ) give us a value of $2.0 \Omega \cdot \mathrm{cm}^{2}$ for $\mathrm{H}_{2}$ operation and $2.6 \Omega \cdot \mathrm{cm}^{2}$ for $\mathrm{CO}$ operation, also here a difference of $0.6 \Omega \cdot \mathrm{cm}^{2}$. This is as expected since the exchange of reactants only affect the electrode kinetics which according to theory should be identical in both directions. The performance of a $\mathrm{CO} / \mathrm{CO}_{2}$ reversible fuel cell system is somewhat lower than of a $\mathrm{H}_{2} / \mathrm{H}_{2} \mathrm{O}$ system as a consequence of both higher ASR and lower $\mathrm{OCV}$, however, this is partly retrieved on the system level since there is no need for energy for steam production. 

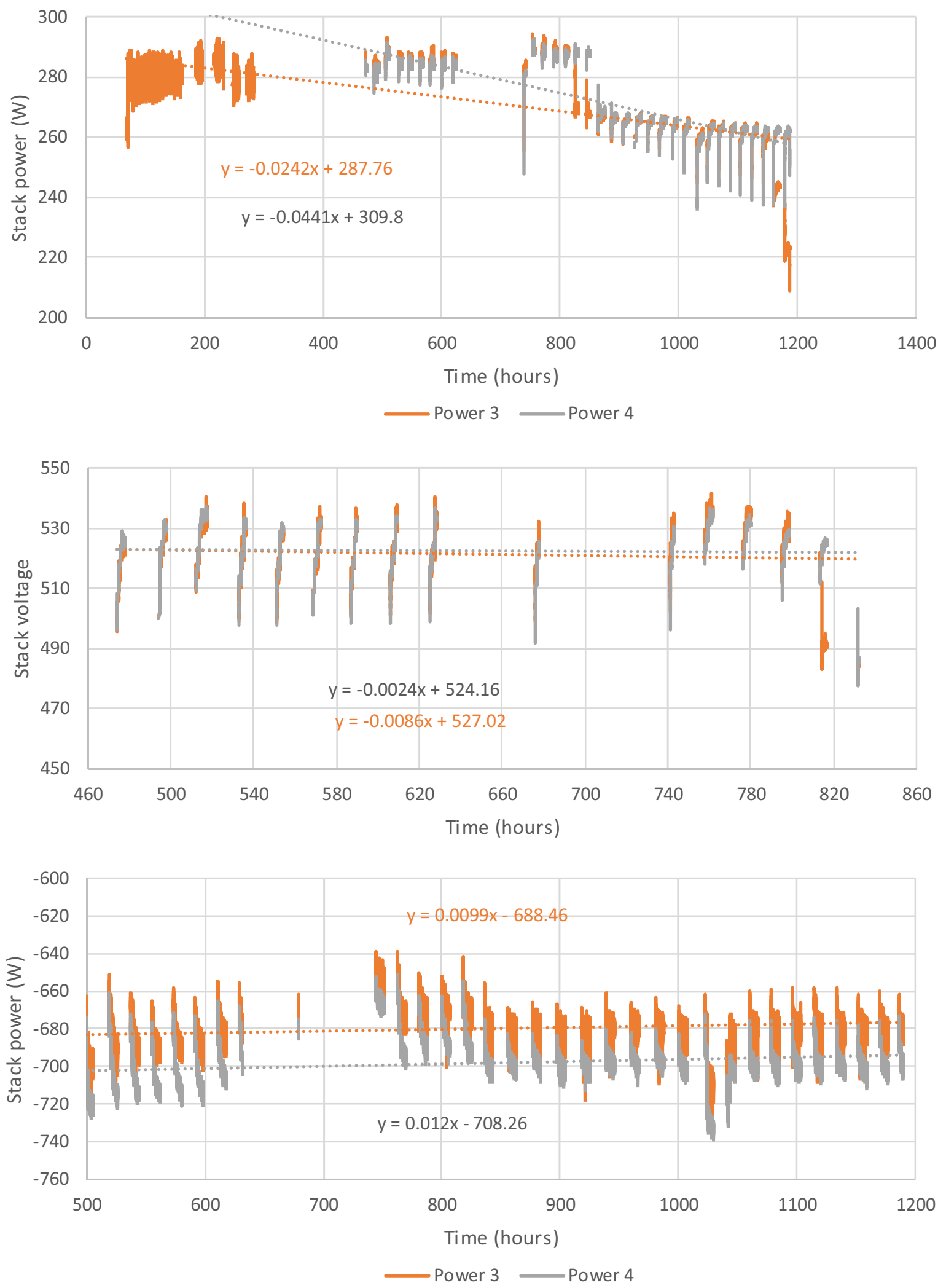

Figure 7. Power vs. time at 10.4 A (top), 20.9 A (middle) and-20.2 A (bottom) 


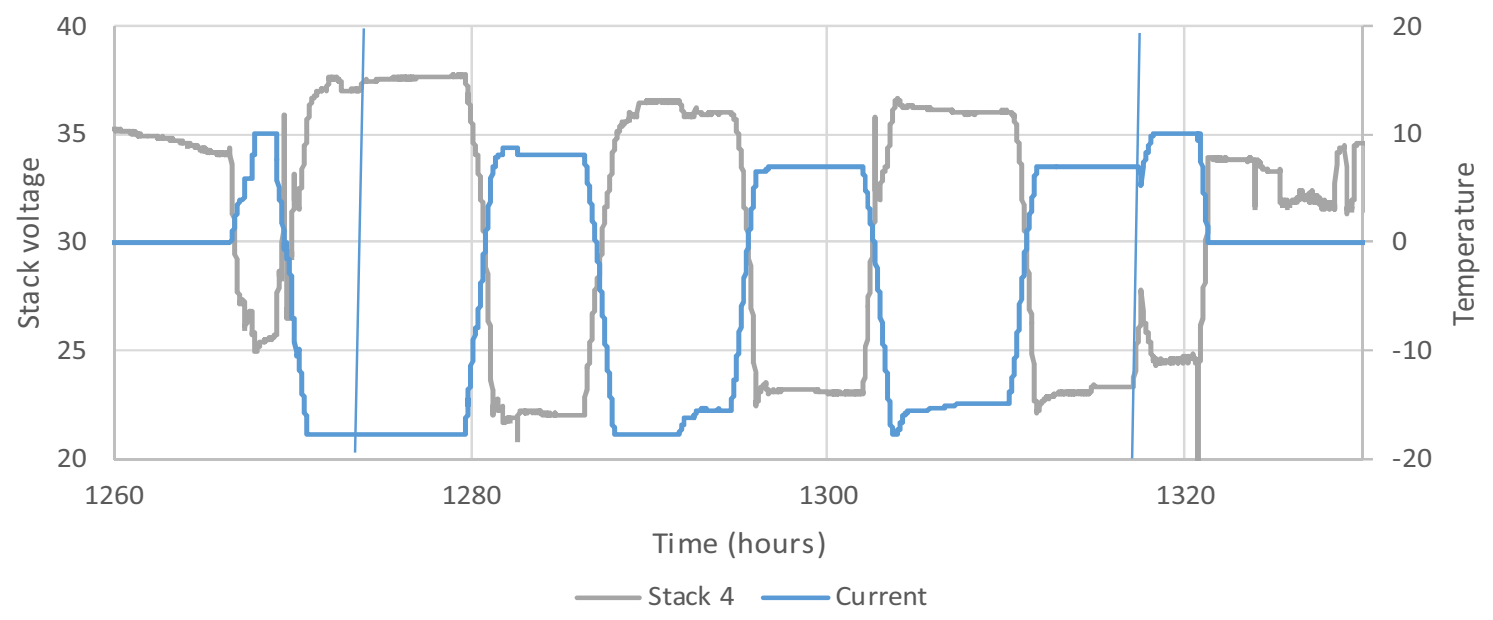

Figure 8. Voltage and current on operation with $\mathrm{CO} / \mathrm{CO}_{2}$

\section{CONCLUSIONS}

The following results and conclusions have been obtained in the project:

- A functional test bench has been manufactured suitable for further development of the technology.

- Sufficient performance and stability for reversible operation can be achieved with the standard SOFC materials used in terrestrial application.

- As long as the mechanical integrity of the stacks is preserved, degradation is not traceable within 1000 hours operation.

- The SOFC can be operated with both $\mathrm{H}_{2} / \mathrm{H}_{2} \mathrm{O}$ and $\mathrm{CO} / \mathrm{CO}_{2}$ as reactants. Lower performance with $\mathrm{CO} / \mathrm{CO}_{2}$ can be partly compensated by increased temperature.

As a final remark, material development, design, manufacture and testing of the $1 \mathrm{~kW}$ RSOFC system have provided invaluable experience and knowledge for the further development of a regenerative energy storage system for space exploration missions. The results also show that all the project success targets have been achieved and no major technological obstacles have been revealed. The development continues within the ongoing ESA project Regenerative fuel cells for Mars exploration, with the Centre for Research \& Technology-Hellas (CERTH) as a partner, on sorbent materials for thermal compression of $\mathrm{CO}_{2}$ at relevant temperature and pressure range (standard mechanical compressors are not viable in space) and tolerant electrocatalyst materials for $\mathrm{CO}$ and $\mathrm{CO}_{2} \mathrm{SOFC/SOEC}$ reversible operation [6].

\section{REFERENCES}

1. Wærnhus, I., Vik, A., Strand, A., Tsiplakides, D., Balomenou, S., \& Papazisi, K. (2011). High temperature fuel cells for future mars missions. 9th European Space Power Conference, Saint Raphael, France.

2. Heggland, O.R., Wærnhus, I., Holst, B. \& Ilea, C.S. Nanopowders for reversible oxygen electrodes in SOFC and SOEC (2012). 10th European SOFC Forum, Lucern, Switzerland. (B0711)

3. Wærnhus, I., Ilea, C.S., Vik, A., Heggland, O.R. \& Holst, B. (2014). Regenerative energy storage system for space exploration missions. 10th European Space Power Conference, Noordwijkerhout, The Netherlands

4. Megel, S., Kusnezoff, M. et al. (2011). High Efficiency CFY-Stack for High Power Applications. ECS Transactions, 35(1). 269-277

5. Megel, S., Kusnezoff, M. et al. (2012). CFY-Stack: from electrolyte supported cells to high efficiency SOFC stacks. 10th European SOFC Forum (A1203)

6. Papazisi, K. M., Tsiplakides D., Balomenou S., Wærnhus, I., Vik, A., Schautz, M., (2016). Carbon tolerant fuel electrodes for reversible SOFC operating on carbon dioxide. 11th European Space Power Conference, Thessaloniki, Greece 